\title{
Effect of Deficit Furrow Irrigation on Yield and Water Productivity of Tomato (Solanum Lycopersicum L.) in Central Rift Valley Intensive Irrigation System at East Shewa Zone, Oromia, Ethiopia
}

\author{
Lemma Teklu Kumsa \\ Oromia Agricultural Research Institute, Bako Agricultural Research Center, \\ P. O. Box 03, Bako, West Shoa, Ethiopia,
}

\begin{abstract}
This study attempted to evaluate the effects of alternative furrow irrigation (AFI), fixed furrow irrigation (FFI) and conventional furrow irrigation (CFI) systems on crop yield and water use efficiencies. The general objective were to study the effect of deficit irrigation on yield and water use efficiency for improved agricultural production, environmental sustainability and water productivity, with specific objectives of investigating the effect of deficit irrigation under different furrow irrigation systems on yield and water use efficiency of tomato. A field experiment was designed as a two factor factorial in RCBD; with three time replicate. The two factors were irrigation systems and water application levels. Irrigation depth was monitored using a Parshall flume of an opening diameter 3 inch with discharge of $3.532 \mathrm{l} / \mathrm{s}$ at a head of $8 \mathrm{~cm}$. Results were compared in terms of flow parameters, water use efficiencies and yield at $(\mathbf{P}<\mathbf{0 . 0 5})$. Flow parameters had shown that, recession time of AFI system was highly significant from both of CFI and FFI systems and $100 \%$ ETc from the remaining three application levels and their interaction was significant. For water use efficiency parameters; the mean results of both crop water use efficiency (CWUE) and field water use efficiency (FWUE) of AFI, FFI and CFI were $256.69,214.77$ and $130.53 \mathrm{kgha}^{-1} \mathrm{~mm}^{-1}$ respectively and showing highly significant difference between them. There were highly significant differences between the mean results of irrigation systems of AFI and CFI systems on Christian's uniformity coefficient (UCC), application efficiency (Ea), storage efficiency (Er) and deep percolation losses (Dp) and Water application levels between $100 \%$ ETc and the remaining three application levels on UCC and Er, while for Ea and Dp between $85 \%$ ETc and $50 \%$ ETc and their interaction were also highly significant. There was no significant difference between the yield obtained from AFI and CFI, However, there were highly significant difference between yield of FFI and CFI systems. In view of the results, AFI system is taken as promising for conservation of water $\left(1232.9 \mathrm{~m}^{3} / \mathrm{ha}\right)$, time $\left(522: 09\right.$ ' $15^{\prime \prime}$ hours/ha) and costs $(187502.00 \mathrm{birr} / \mathrm{ha})$ without negligible tradeoff in yield.
\end{abstract}

Key words: Deficit Irrigation, Irrigation systems, Water use efficiency and Tomato yield.

\section{INTRODUCTION}

Increased agricultural production has become an urgent requirement of the expanding world population (Chen et al., 2011). Yet, there has been a continued decrease in available fresh water that can be used by agricultural production (Cai and Rosegrant, 2003). As a result, deficit irrigation has been prevalently used in irrigated agriculture. Deficit irrigation can lead to greater economic gains by maximizing yield per unit of water applied under conditions of scarce water supply and drought, as well as by increasing of cultivable frequency or irrigable area (Bekele and Tilahun, 2007; Kifle and Gebretsadikan,2016). The expectation is that, any yield reduction will be insignificant compared with the benefits that are gained from the conservation of water. But, its effects on yield or harvest quality are crop specific (Costa et al., 2007).

In Ethiopia, most irrigators allocate irrigation water to their field below the maximum crop water requirement for maximum yield because of the limited water and high level of competition at tail of scheme (Lorite et al., 2007). Most of irrigation in Ethiopia $(97.8 \%)$ is done by surface irrigation methods, especially by furrow system in farmer's fields and majority of the commercial farms (FAO, 2001; Lemma, 2017). The furrow irrigation systems were includes conventional furrow irrigation (CFI), fixed furrow irrigation (FFI) and alternative furrow irrigation (AFI). CFI is where every furrow is irrigated during consecutive watering, is known to be less efficient particularly in areas where there is shortage of irrigation water. The development towards optimum utilization of irrigation is to irrigate alternate furrows during each irrigation time (Zhang et al., 2000). By irrigating alternative furrows, half of root is exposed to wet soil condition and the other half is exposed to dry soil condition. According Hodges et al., 1989 and Graterol et al., 1993, FFI is a means of selection some furrows for irrigation while other adjacent furrows were not irrigated for the whole season.

Tomato (Solanum lycopersicon L.) is one of the most important irrigated vegetable crops and is one of the most demanding in terms of water use (Peet, 2005). The application of various deficit irrigation strategies to this crop may significantly led to save irrigation water (Costa et al., 2007). According to Patane et al. (2011), the adoption of deficit irrigation strategies in which a $50 \%$ reduction in ETc was applied for the whole or partial growing season to save water helped to minimize fruit losses and maintain high fruit quality. 
In the study area, poor rainfall distribution and over application of irrigation water without determining the crop water requirement were identified as the major problem of a crop failure. Under such existing condition, practicing of deficit irrigation and water saving methods of furrow irrigation systems could help to increase agricultural production by expanding irrigable land with the given limited amount of water. Therefore, this study aims with the objectives to evaluate the effect of deficit irrigation under furrow irrigation methods on yield and water use efficiency of tomato for improved agricultural production, environmental sustainability and water productivity.

\section{Study Area Description}

\section{MATERIALS AND METHODS}

The experimental site is situated at Dugda district, Eastern Shoa zone, Central Ethiopia. It is located at $130 \mathrm{~km}$ away from Addis Ababa to Ziway at South East direction from Meki town at an altitude of $1685 \mathrm{~m}$ a s 1 (Fig. 1). The experimental site is characterized by sandy loam soil type, mild and warm temperate climate in which the majority of the rainfall occurs from May to September. Rainfall over the district is highly variable in temporal and spatial. The area receives an annual rainfall of 1009 $\mathrm{mm}$ and an average annual temperature of $18.4^{\circ} \mathrm{C}$ (en.climate-data.org/4437/).

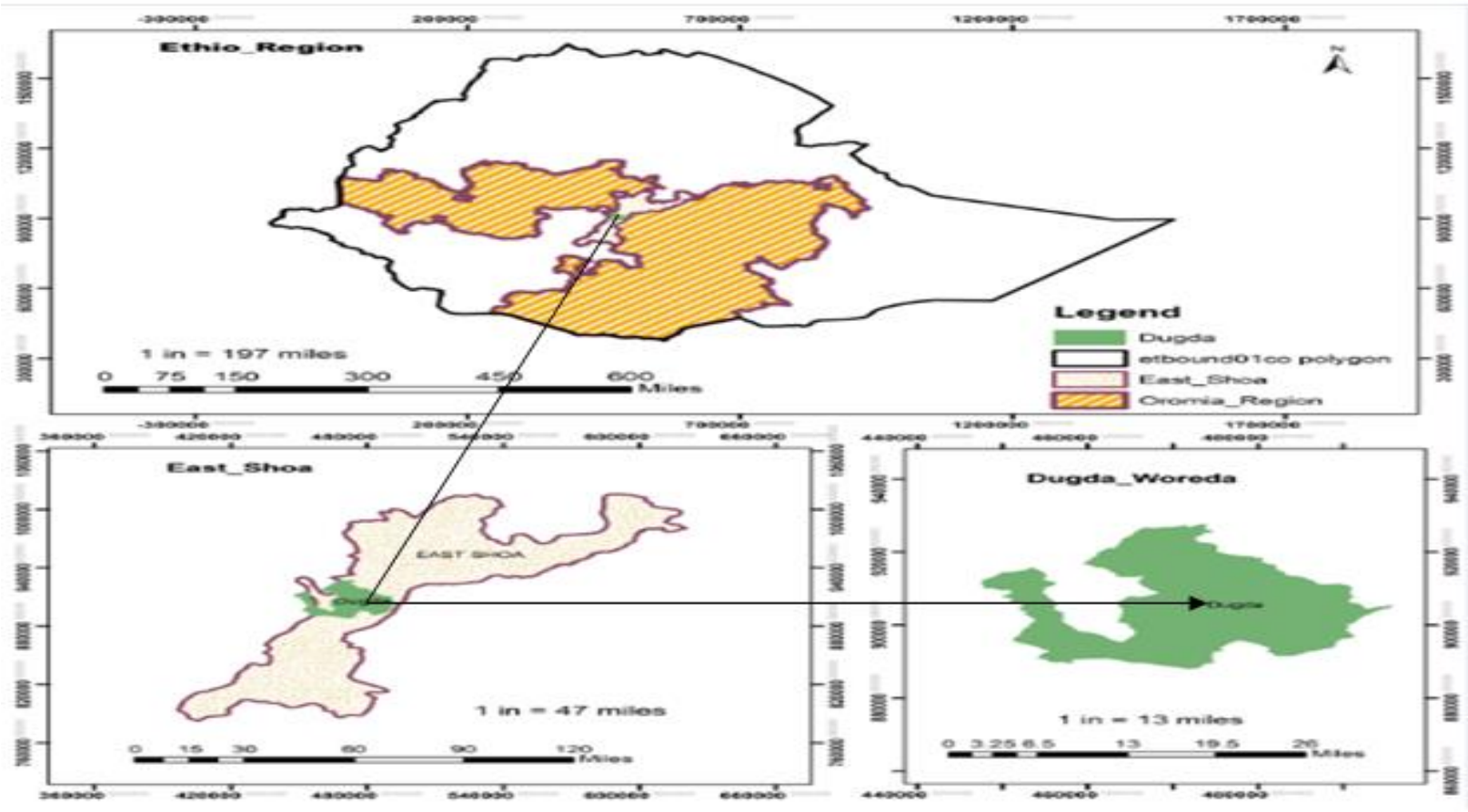

Fig.1. Location map of the study area

\section{Experimental Design and Procedure}

The experiment was implemented in two factorial combinations namely, three irrigation systems and four irrigation water application levels (Table 1). The treatments combinations were arranged as completely randomized blocks design with three time replications. The depth of water applied to the field was measured by Parshall Flume of 3inch throat diameter. The effective head of $8 \mathrm{~cm}$ was calibrated and hence the resulting discharge was $3.532 \mathrm{l} / \mathrm{s}$. The plot size was $4 \mathrm{~m} \times 6 \mathrm{~m}$ with $1 \mathrm{~m}$ and $2 \mathrm{~m}$ space between plots and blocks respectively. Each plot contained four ridges and four furrows. Each bed had $1 \mathrm{~m}$ width and $6 \mathrm{~m}$ length. The trapezoidal shape furrow was prepared with an average depth of $30 \mathrm{~cm}$ and width of $25 \mathrm{~cm}$ and $15 \mathrm{~cm}$ at the top and bottom, respectively.

Improved tomato Galilea variety having a total growing period of 75 days after transplanting was grown in a modern green house for 21 days and transplanted on experimental plot. The crop variety was selected for its good adaptability, disease resistant and most usable in the study area.

Table.1. Treatments used for the experiment

\begin{tabular}{cllll}
\hline Irrigation systems & \multicolumn{3}{c}{ Water application levels } \\
\cline { 2 - 5 } & $100 \%$ ETc & $85 \%$ ETc & $70 \%$ ETc & $50 \%$ ETc \\
\hline AFI & AFI100\% ETc & AFI 85\% ETc & AFI 70\% ETc & AFI 50\% ETc \\
FFI & FFI100\% ETc & FFI 85\% ETc & FFI 70\% ETc & FFI 50\% ETc \\
CFI & CFI100\% ETc & CFI 85\% ETc & CFI 70\% ETc & CFI 50\% ETc \\
\hline
\end{tabular}

Where: AFI100\% ETc, FFI100\% ETc and CFI100\% ETc were alternative, fixed and conventional furrow irrigation with full irrigation respectively, AFI 85\% ETc, FFI 85\% ETc and CFI 85\% ETc were 85\% of the full irrigation (15\% deficit), AFI 70\% ETc, FFI 70\% ETc and CFI 70\% ETc were 70\% of full irrigation (30\% deficit) and AFI 50\% ETc, FFI 50\% ETc and CFI 50\% ETc were $50 \%$ of full irrigation (50\% deficit). 


\section{Soil Sample Collection and Analysis Methods}

Depending on the greatest root depth concentration which is $30 \mathrm{~cm}$ for transplanted tomatoes, the disturbed and undisturbed composite soil sample before planting were collected at a depth of 0-20 and 20-40 cm. Different soil physical properties such as bulk density, texture, infiltration, field capacity and permanent wilting point were done by core sampler method, pipette method, double ring infiltrometer, pressure plate apparatus by applying a suction of $1 / 3$ and 15 bars to a saturated soil sample, respectively.

\section{Determination of Crop Water and Irrigation Requirement}

Crop water requirement of tomato for the growing season was determined from the reference evapotranspiration and crop coefficient using Equation (1). Soil (Table 2) and Meteorological data's (Table 3) were used to determine reference crop evapotranspiration (ETo). Farmers' experience was used to determine the numbers of days of each growing stages to estimate reliable $\mathrm{Kc}$ for the respective growing stages. A higher value of application efficiency (60\%) was adopted, because water was applied more accurately and no runoff. Irrigation scheduling of the crop was computed using FAO CROPWAT program (Allen et al., 1998).

$$
\mathrm{ETc}=\mathrm{Kc} \times \mathrm{ETo}
$$

Where: $\mathrm{ETc}=$ crop evapotranspiration $(\mathrm{mm} /$ day $)$,

$\mathrm{Kc}=$ crop coefficient (dimensionless), and

$\mathrm{ETo}=$ reference crop evapotranspiration $(\mathrm{mm} / \mathrm{day})$.

\begin{tabular}{|c|c|c|c|c|c|c|c|c|}
\hline Depth of sampling $(\mathrm{cm})$ & $\begin{array}{l}\text { FC (\%) } \\
\text { by vol. }\end{array}$ & $\begin{array}{l}\text { PWP (\%) by } \\
\text { vol. }\end{array}$ & $\begin{array}{l}\mathrm{Bd} \\
\left(\mathrm{g} / \mathrm{cm}^{3}\right)\end{array}$ & $\begin{array}{l}\text { Sand } \\
\%\end{array}$ & $\begin{array}{l}\text { Silt } \\
\%\end{array}$ & $\begin{array}{l}\text { Clay } \\
\%\end{array}$ & $\begin{array}{l}\text { Textural } \\
\text { class }\end{array}$ & $\begin{array}{l}\text { Infiltration rate } \\
(\mathrm{mm} / \mathrm{hr})\end{array}$ \\
\hline $0-20$ & 23.77 & 12.28 & 1.32 & 71 & 8 & 21 & Sandy loam & \multirow{3}{*}{28.8} \\
\hline $20-40$ & 20.10 & 11.89 & 1.34 & 69 & 14 & 17 & Sandy loam & \\
\hline Average & 21.94 & 12.09 & 1.33 & 70 & 11 & 19 & Sandy loam & \\
\hline
\end{tabular}

Where: FC, PWP and Bd were field capacity, permanent wilting point and bulk density respectively.

Table.3. Climate data and ETo value of the study area

\begin{tabular}{|c|c|c|c|c|c|c|}
\hline Months & $\begin{array}{l}\text { Temp. } \\
\max .\left({ }^{\circ} \mathrm{C}\right)\end{array}$ & Temp. min. $\left({ }^{0} \mathrm{C}\right)$ & Humidity (\%) & Wind speed $(\mathrm{km} / \mathrm{hr})$ & Sun shine (hr) & ETo (mm/day) \\
\hline January & 27.295 & 12.519 & 49 & 1.6 & 9.8 & 3.38 \\
\hline February & 28.967 & 13.5 & 45.4 & 1.7 & 9.5 & 3.69 \\
\hline March & 29.428 & 15.179 & 41 & 1.6 & 9.1 & 3.91 \\
\hline April & 29.553 & 15.89 & 57 & 1.6 & 8.8 & 4.17 \\
\hline May & 29.395 & 16.175 & 58.4 & 1.8 & 8 & 3.92 \\
\hline June & 28.125 & 15.775 & 59.8 & 2.4 & 8.1 & 3.81 \\
\hline July & 25.586 & 15.31 & 66.7 & 2.2 & 6.3 & 3.38 \\
\hline August & 25.719 & 15.181 & 73.6 & 1.9 & 6.1 & 3.43 \\
\hline September & 26.86 & 14.668 & 72.6 & 1.4 & 6.4 & 3.54 \\
\hline October & 27.75 & 13.237 & 69.2 & 1.5 & 9.2 & 3.98 \\
\hline November & 27.245 & 12.165 & 63 & 1.7 & 9.8 & 3.68 \\
\hline December & 26.642 & 11.342 & 55.3 & 1.7 & 9.8 & 3.3 \\
\hline
\end{tabular}

Source: National Meteorological Organization, Batu station, 1985-2015 G.C

\section{Crop Agronomy and Management}

Tomato seedlings were transplanted to the experimental plots based on the recommended space of $60 \mathrm{~cm}$ between plants and $100 \mathrm{~cm}$ row spacing. Recommended fertilizer of $200 \mathrm{~kg} / \mathrm{ha}$ DAP at the time of transplanting and $150 \mathrm{~kg} / \mathrm{ha}$ Urea twice, half at the time of transplanting while, half at 21 days after transplanting were equally and uniformly applied to each treatments. The crop was cultivated and weeded four times during the growing season. It was transplanted on four ridges of each plot and for further analysis; the yield were harvested from the two central ridges only to avoid boarder effects.

\section{Soil Moisture Determination}

Soil moisture were monitored both at field condition by installing a tensiometer at different depth of 30,40 and $60 \mathrm{~cm}$ and laboratory by taking undisturbed soil sample. Soil samples were taken at 24 hours after irrigation and one day left before next irrigation depending on irrigation interval from the third furrow of each plot at depths of 0-20 and $20-40 \mathrm{~cm}$ at locations of $3 \mathrm{~m}$ 
from a head of furrow. The collected soil samples were placed in an oven set at a temperature of $105^{\circ} \mathrm{C}$ and dried for $24 \mathrm{hrs}$. Its gravimetric and volumetric water content was determined using formula 2 and 3 (Cuenca, 1989).

$$
\theta_{\mathrm{dw}}=\left\lceil\frac{\mathrm{W}_{\mathrm{ws}}-\mathrm{W}_{\mathrm{ds}}}{\mathrm{w}_{\mathrm{ds}}}\right\rceil \times 100
$$

Where: Wws= weight of wet soil, $(\mathrm{g})$

$$
\begin{aligned}
\theta_{\mathrm{dw}} & =\text { water content expressed on weight basis in }(\%) \\
\mathrm{W}_{\mathrm{ds}} & =\text { weight of dry soil, }(\mathrm{g}) \\
\theta_{v} & =\frac{\rho_{b}}{\rho_{w}} \times \theta_{\mathrm{dw}} \times 100
\end{aligned}
$$

Where: $\theta_{v}=$ Volumetric moisture content in $(\%)$

$\rho_{b}=$ Soil bulk density, $\left(\mathrm{g} / \mathrm{cm}^{3}\right)$

$\rho \mathrm{w}=$ Water density $\mathrm{g} / \mathrm{cm}^{3},\left(1 \mathrm{~g} / \mathrm{cm}^{3}\right)$

$\theta_{\mathrm{dw}}=$ as expressed in equation 2

\section{Depth and discharge mmeasurement}

The total amount of water requirement for the crop was diverted to the furrow with calibrated parshall flume having appropriate opening diameter of three inch (3") with a length of $2 \mathrm{~m}$ and its appropriate head ranges from 3-33cm. It was calculated as suggested by Michael, (2008):

$$
\mathrm{Q}=0.1771 \mathrm{~h}^{1.5}
$$

Where: $\mathrm{Q}=$ discharge from parshall flume, $(1 / \mathrm{s})$ $\mathrm{h}=$ effective head of Parshall flume causing flow, $(\mathrm{cm})$

The time required to deliver the desired depth of water into each furrow was calculated using the equation recommended by Israelsen (1980).

$$
t=\frac{d \times w \times l}{360 \times q}
$$

Where: $\mathrm{d}=$ gross depth of water applied, $(\mathrm{cm})$

$$
\begin{aligned}
& \mathrm{t}=\text { application time },(\mathrm{hr}) \\
& \mathrm{l}=\text { furrow length in }(\mathrm{m}) \\
& \mathrm{w}=\text { furrow spacing in, }(\mathrm{m}) \\
& \mathrm{q}=\text { flow rate (discharge) },(1 / \mathrm{s})
\end{aligned}
$$

\section{Flow Time Measurement}

The advancing, application and recession time was monitored using stopwatch during each irrigation water application in order to assess the treatment effects on flow parameters.

\section{Calculation and analysis of basic parameters}

\section{Advance rate computation}

$$
\mathrm{AR}=\frac{\mathrm{LT}}{\mathrm{AT}}
$$

Where: $\mathrm{AR}=$ advance rate, $(\mathrm{m} / \mathrm{s})$

LT = length travelled by water, furrow length, (m)

$\mathrm{AT}=$ time taken by water to travel from head to the tail of furrow, (s)

\section{Distribution uniformity}

$$
\mathrm{UCC}=\left[1-\frac{\sum_{\mathrm{i}=1}^{\mathrm{n}}\left|\theta_{\mathrm{i}}-\bar{\theta}\right|}{\bar{\theta} \mathrm{N}}\right] \times 100
$$

Where: $\mathrm{UCC}=$ Christian's uniformity coefficient, in \%

$\theta_{\mathrm{i}}=$ observed water content for the $\mathrm{i}^{\mathrm{th}}$ point, in $\mathrm{cm}^{3}$ (from gravimetric moisture determination).

$\mathrm{N}=$ number of points where samples was taken. $\mathrm{N}$ is $1,2,3 \ldots 36$, because uniformity was computed for each treatment

$\bar{\theta}=$ mean water content

Mean water content is determined by:

$$
\bar{\theta}=\frac{\sum_{\mathrm{i}=1}^{\mathrm{n}} \theta_{\mathrm{i}}}{\mathrm{N}}
$$

Application efficiency

$$
\mathrm{E}_{\mathrm{a}}=\frac{\mathrm{W}_{\mathrm{s}}}{\mathrm{W}_{\mathrm{f}}} \times 100
$$

Where: $\mathrm{Ea}=$ Application efficiency $(\%)$

$\mathrm{Ws}=$ water stored in the root zone, $(\mathrm{mm})$

$\mathrm{Wf}=$ water applied to the field, $(\mathrm{mm})$

\section{Deep percolation fraction}

$$
\text { Df }=100-E_{a}-R f
$$

Where: $\mathrm{Rf}=$ amount of runoff during irrigation, $(\mathrm{mm})$

$\mathrm{Ea}=$ as defined in equation 3 
Storage efficiency

$\mathrm{Df}=$ amount of water deep percolated during irrigation, $(\mathrm{mm})$

$$
E r=\frac{\mathrm{W}_{\mathrm{S}}}{\mathrm{W}_{\mathrm{n}}} \times 100
$$

Where: $\mathrm{Er}=$ storage efficiency $(\%)$

$\mathrm{Ws}=$ water stored in the root zone during irrigation, $(\mathrm{cm})$

$\mathrm{Wn}=$ water needed in the root zone prior to irrigation, $(\mathrm{cm})$

\section{Yield assessments $(y)$}

Yield obtained in ton per ha $=\mathrm{y} \times 10^{4}$

Where: $y=$ yield obtained per square meter

\section{Water use efficiency \\ Crop water use efficiency}

$$
\mathrm{CWUE}=\frac{\mathrm{y}}{\mathrm{ETc}}
$$

Where: CWUE = crop water use efficiency $(\mathrm{kg} / \mathrm{ha}-\mathrm{mm})$

$\mathrm{Y}=$ yield in $\mathrm{Kg} \mathrm{ha}^{-1}$ and

ETc $=$ evapotranspiration $(\mathrm{mm})$

\section{Field water use efficiency}

$$
\text { FWUE }=\frac{\mathrm{y}}{\text { Net irrigation }}
$$

Where: FWUE = field water use efficiency $(\mathrm{kg} / \mathrm{ha}-\mathrm{mm})$

$$
\mathrm{Y}=\text { yield (ton/ha) }
$$

Net irrigation $(\mathrm{mm})$

\section{Statistical Analysis}

The collected data were analyzed using GenStat $18^{\text {th }}$ edition, ANOVA and the mean difference was estimated using the least significance difference (LSD) comparisons.

\section{RESULTS AND DISCUSSIONS}

\section{Crop water requirements and irrigation scheduling of tomato}

The seasonal net irrigation water requirement of tomato was found to be $246.58 \mathrm{~mm}$ for $100 \%$ ETc (full irrigation) with CFI, AFI, FFI systems (Table 4). Accordingly, $85 \%, 70 \%$ and $50 \%$ of $100 \%$ ETc with CFI, AFI, and FFI levels were $210 \mathrm{~mm}, 173$ $\mathrm{mm}$ and $124 \mathrm{~mm}$, respectively.

The results indicated that, the maximum depth of water was applied during the mid development stage (mid March) of tomato. According to Sahasrabudhe (1996) suggestion, this stage is the time when the crop needs high amount of water for the development of flowers and fruit which is high energy demanding and peak physiological phase for the crop growth. The development stage is also the time during which the plants achieve higher canopy coverage and undergoing higher transpiration

\begin{tabular}{|c|c|c|c|c|c|c|}
\hline \multirow{2}{*}{$\begin{array}{l}\text { Irrigation } \\
\text { systems }\end{array}$} & \multirow{2}{*}{$\begin{array}{c}\text { Water } \\
\text { application levels }\end{array}$} & \multicolumn{5}{|c|}{ Irrigation period and depth of applied water (mm) } \\
\hline & & $4^{\text {th }}$ February & $15^{\text {th }}$ February & $1^{\text {st }}$ March & $15^{\text {th }}$ March & $31^{\text {st }}$ March \\
\hline \multirow{4}{*}{ FFI } & $100 \%$ ETc & 21.08 & 27.68 & 63.27 & 67.62 & 66.93 \\
\hline & $85 \%$ ETc & 17.92 & 23.53 & 53.78 & 57.48 & 56.89 \\
\hline & $70 \% \mathrm{ETc}$ & 14.78 & 19.34 & 44.29 & 47.33 & 46.85 \\
\hline & $50 \% \mathrm{ETc}$ & 10.54 & 13.84 & 31.64 & 33.81 & 33.47 \\
\hline \multirow{8}{*}{ AFI } & $100 \%$ ETc & 21.08 & 27.68 & 63.27 & 67.62 & 65.93 \\
\hline & $85 \%$ ETc & 17.92 & 23.53 & 53.78 & 57.48 & 56.89 \\
\hline & $70 \% \mathrm{ETc}$ & 14.78 & 19.34 & 44.29 & 47.33 & 46.85 \\
\hline & $50 \% \mathrm{ETc}$ & 10.54 & 13.84 & 31.64 & 33.81 & 33.47 \\
\hline & $100 \% \mathrm{ETc}$ & 21.08 & 27.68 & 63.27 & 67.62 & 65.93 \\
\hline & $85 \%$ ETc & 17.92 & 23.53 & 53.78 & 57.48 & 56.89 \\
\hline & $70 \% \mathrm{ETc}$ & 14.78 & 19.34 & 44.29 & 47.33 & 46.85 \\
\hline & $50 \% \mathrm{ETc}$ & 10.54 & 13.84 & 31.64 & 33.81 & 33.47 \\
\hline
\end{tabular}
rate. Maximization of crop yield and quality can be achieved through meeting crop water requirement during this critical period, given all other factors are met.

Table 4. Irrigation interval and depth of water applied to each treatment

FFI, AFI and CFI are fixed furrow irrigation, alternative furrow irrigation and conventional furrow irrigation, respectively.

Effects of Irrigation Systems and Water Application Levels on Flow Parameters

\section{Advance rate}

The time required for the water to advance to cover the field completely is an important consideration in managing surface irrigation systems. According to analysis of variance (Table 5), there is no significant difference among the three irrigation systems, water application levels and their interaction at $(\mathrm{p}<0.05)$ in terms of advance rate. The probable reason for the non significance of the irrigation systems and water application levels on advance rate was the shortness of the furrow length of the experimental plots. 
Table 5. Analysis of variance of flow parameters

\begin{tabular}{lcc}
\hline \multicolumn{1}{c}{ Source of variation } & \multicolumn{2}{c}{ Flow parameters } \\
\hline Irrigation systems & Advance rate & Recession time \\
Water application levels & $0.94^{\mathrm{NS}}$ & $35.52^{* *}$ \\
Irrigation systems x water application levels & $0.83^{\mathrm{NS}}$ & $47.39^{* *}$ \\
& $0.89^{\mathrm{NS}}$ & $3.30^{*}$ \\
\hline $\mathrm{CV}(\%)$ & $9.84 \%$ & $4.90 \%$ \\
\hline $\mathrm{LSD}_{0.05}$ & 0.61 & 6.40 \\
\hline
\end{tabular}

Where: NS- non significant, *-significant, **-highly significant

\section{RECESSION TIME}

Irrigation systems and water application levels were highly significant at $(\mathrm{p}<0.01)$, while their interaction were significant $(\mathrm{p}<0.05)$ in terms of recession time (Table 5). Recession time of AFI system was significantly different from both CFI and FFI systems, but there were no significant difference between CFI and FFI systems. The probable reason for this could be the difference in soil-water potential between the three irrigation systems which makes the recession time different. The water suction of CFI may be smaller and need longer recession time than AFI and FFI. In an AFI, soil desiccations was higher with low soil water potential due to alternate wetting of neighboring furrows and the recession time is shorter. In FFI system, the neighboring furrow stays dry during the whole irrigation period and the lateral movement subsequently higher than the rate of infiltration. This is consistent with the results of slower recession time that have been associated with AFI and FFI (Hodges et al., 1989; Woldesenbet, 2005).

Water application levels of $100 \%$ ETc was significantly different from the remaining three application levels, $85 \%$ ETc and $70 \%$ ETc and 50\% ETc. But, no significant difference between water application levels of 85\% ETc and 70\% ETc (Table 6). The result indicates that, the time needed for recession depends on the depth of irrigation water applied.

Table 6. Effects of irrigation systems and water application levels on recession time

\begin{tabular}{|c|c|c|c|c|c|c|c|}
\hline \multirow[t]{2}{*}{ Flow parameters } & \multicolumn{3}{|c|}{ Irrigation systems } & \multicolumn{4}{|c|}{ Water application levels } \\
\hline & CFI & FFI & AFI & $100 \%$ ETc & $85 \%$ ETc & $70 \%$ ETc & $50 \%$ ETc \\
\hline Recession time & $83.36^{\mathrm{a}}$ & $77.10^{\mathrm{a}}$ & $70.44^{\mathrm{b}}$ & $87.33^{\mathrm{a}}$ & $80.33^{\mathrm{b}}$ & $74.33^{\mathrm{b}}$ & $66.89^{c}$ \\
\hline Mean & \multicolumn{3}{|c|}{76.97} & \multirow{2}{*}{\multicolumn{4}{|c|}{6.97}} \\
\hline $\mathrm{CV}$ & \multirow{2}{*}{\multicolumn{3}{|c|}{$\begin{array}{l}4.90 \% \\
\quad 6.40\end{array}$}} & & & & \\
\hline LSD0.05 & & & & \multicolumn{4}{|c|}{6.43} \\
\hline $\mathrm{SE} \pm$ & \multicolumn{3}{|c|}{3.09} & \multicolumn{4}{|c|}{3.19} \\
\hline
\end{tabular}

Where: CFI- conventional furrow irrigation, FFI- fixed furrow irrigation, AFI- alternative furrow irrigation

As indicated on two ways Table (7), recession time of CFI and FFI systems were significantly different between $100 \%$ ETc and the remaining three application levels, $85 \%$ ETc and 50\% ETc and also between 70\% ETc and 50\% ETc for CFI system. This indicates that, the recession time of CFI and FFI systems were affected by water application levels. But under AFI system, recession time of water application levels at 50\% ETc was significantly different from the three application levels, while there were no significant difference among $100 \%$ ETc, $85 \%$ ETc and $70 \%$ ETc. This shows that, as the irrigation water applied levels decreases under AFI, the recession time became short due to the alternate wetting pattern of the furrow.

Table 7.Two-way table of mean recession time ( $\mathrm{min})$

\begin{tabular}{|c|c|c|c|c|c|}
\hline \multirow[t]{2}{*}{ Irrigation systems } & \multicolumn{4}{|c|}{ Water application levels } & \multirow[t]{2}{*}{ Mean } \\
\hline & $100 \% \mathrm{ETc}$ & $85 \% \mathrm{ETc}$ & $70 \%$ ETc & $50 \% \mathrm{ETc}$ & \\
\hline FFI & $86.78^{\mathrm{a}}$ & $78.27^{\mathrm{b}}$ & $73.44^{\mathrm{cb}}$ & $69.89^{\mathrm{dc}}$ & 77.01 \\
\hline AFI & $76.11^{\mathrm{a}}$ & $74.00^{\mathrm{a}}$ & $71.22^{\mathrm{a}}$ & $60.44^{\mathrm{b}}$ & 70.44 \\
\hline CFI & $99.11^{\mathrm{a}}$ & $84.33^{\mathrm{b}}$ & $78.34^{\mathrm{cb}}$ & $71.67^{\mathrm{c}}$ & 83.36 \\
\hline Mean & 86.91 & 78.45 & 73.91 & 68.47 & 76.94 \\
\hline $\mathrm{LSD}_{0.05}$ & & & 7.39 & & \\
\hline $\mathrm{CV}(\%)$ & & & $4.9 \%$ & & \\
\hline
\end{tabular}




\section{Effects of Irrigation Systems and Water Application Levels on Water Use Efficiency (WUE) Parameters Distribution uniformity (DU)}

According to the analysis of variance (Table 8$)$, there were highly significant difference at $(\mathrm{p}<0.01)$ among the three irrigation systems and water application levels in terms of UCC. As indicated on Table 9, UCC of CFI system and 100\% ETc were significantly different from AFI system and $85 \%$ ETc, $70 \%$ ETc and 50\% ETc application levels, respectively. But, no significant difference between CFI and FFI, AFI and FFI systems and among the remaining three water application levels. This is not consistent with Woldesenbet, (2005) who reported that UCC is not affected by irrigation systems rather than application levels

Table 8. Analyses of variance for water use efficiency parameters and yield

\begin{tabular}{|c|c|c|c|c|c|c|}
\hline \multicolumn{7}{|c|}{ Water use efficiency parameters } \\
\hline & $\overline{D U}$ & $\mathrm{Ea}$ & $\mathrm{Er}$ & $\mathrm{Dp}$ & $\mathrm{y}$ & $(\mathrm{C} \& \mathrm{~F}) \mathrm{WUE}$ \\
\hline $\begin{array}{l}\text { Irrigation systems } \\
\text { Water application levels } \\
\text { Irrigation systems x } \\
\text { water application levels }\end{array}$ & $\begin{array}{l}11.27 * * \\
11.81 * * \\
3.84 * *\end{array}$ & $\begin{array}{l}23.74 * * \\
5.62 * * \\
9.68 * *\end{array}$ & $\begin{array}{l}5.91 * * \\
83.16 * * \\
1.58^{\mathrm{NS}}\end{array}$ & $\begin{array}{l}19.12 * * \\
5.24 * * \\
10.06 * *\end{array}$ & $\begin{array}{c}22.18 * * \\
111.79 * * \\
6.58 * *\end{array}$ & $\begin{array}{c}99.46^{* * *} \\
0.70^{\mathrm{NS}} \\
1.44^{\mathrm{NS}}\end{array}$ \\
\hline $\mathrm{CV}(\%)$ & $1.77 \%$ & $3.29 \%$ & $2.23 \%$ & $4.34 \%$ & $8.7 \%$ & $11.12 \%$ \\
\hline $\mathrm{LSD}_{0.05}$ & 2.40 & 3.25 & 2.46 & 3.09 & 1.696 & 37.79 \\
\hline
\end{tabular}

Where: NS- non significant, **-highly significant, DU- distribution uniformity, Ea- application efficiency, Erstorage efficiency, Dp-deep percolation, y-yield, (C \& F) WUE- Crop and field water use efficiency.

Table 9. Effects of irrigation systems and water application levels on distribution uniformity

\begin{tabular}{|c|c|c|c|c|c|c|c|}
\hline \multirow[t]{2}{*}{ WUE parameters } & \multicolumn{3}{|c|}{ Irrigation systems } & \multicolumn{4}{|c|}{ Water application levels } \\
\hline & CFI & FFI & AFI & $100 \%$ ETc & $85 \%$ ETc & $70 \%$ ETc & $50 \% \mathrm{ETc}$ \\
\hline DU & $81.75^{\mathrm{a}}$ & $80.21^{\mathrm{ab}}$ & $79.01^{\mathrm{b}}$ & $82.68^{\mathrm{a}}$ & $80.09^{\mathrm{b}}$ & $79.34^{\mathrm{b}}$ & $79.18^{\mathrm{b}}$ \\
\hline Mean & \multicolumn{7}{|c|}{80.32} \\
\hline $\mathrm{CV}$ & \multicolumn{7}{|c|}{$1.77 \%$} \\
\hline LSD0.05 & \multirow{2}{*}{\multicolumn{7}{|c|}{$1.18^{2.40}$}} \\
\hline $\mathrm{SE} \pm$ & & & & & & & \\
\hline
\end{tabular}

Interaction effects between irrigation systems and water application levels were highly significant at $(\mathrm{p}<0.01)$ on DU $($ Table 10$)$. DU of FFI system at water application level of 50\% ETc was significantly affected than the remaining water application levels of $100 \%$ ETc, $85 \%$ ETc and $70 \%$ ETc. Moreover, CFI system is better in DU at $100 \%$ ETc which is significantly different from the remaining three application levels. While water application levels at 70\% ETc was significantly affects DU under AFI systems than the remaining water application levels of $100 \%$ ETc, $85 \%$ ETc and 50\% ETc. And DU in AFI system increases from $70 \%$ ETc to $50 \%$ ETc water application levels. This is because of the soil-water potential difference and suction force of the soil, as the lateral flow to the dry area is greater than the rate of infiltration in this case.

Table 10.Two-way table of mean DU (\%)

\begin{tabular}{|c|c|c|c|c|c|}
\hline \multirow[t]{2}{*}{ Irrigation systems } & \multicolumn{4}{|c|}{ Water application levels } & \multirow[t]{2}{*}{ Mean } \\
\hline & $100 \%$ ETc & $85 \%$ ETc & $70 \% \mathrm{ETc}$ & $50 \% \mathrm{ETc}$ & \\
\hline FFI & $82.32^{\mathrm{a}}$ & $80.04^{\mathrm{a}}$ & $80.91^{\mathrm{a}}$ & $77.57^{\mathrm{b}}$ & 80.21 \\
\hline AFI & $80.67^{\mathrm{a}}$ & $79.60^{\mathrm{a}}$ & $76.05^{\mathrm{b}}$ & $79.69^{\mathrm{a}}$ & 79.00 \\
\hline CFI & $85.04^{\mathrm{a}}$ & $80.62^{\mathrm{b}}$ & $80.07^{\mathrm{b}}$ & $80.26^{\mathrm{b}}$ & 81.50 \\
\hline Mean & 82.68 & 80.09 & 79.01 & 79.17 & 80.24 \\
\hline $\mathrm{LSD}_{0.05}$ & \multicolumn{2}{|c|}{2.40} & & & \\
\hline $\mathrm{CV}(\%)$ & \multicolumn{2}{|c|}{$1.77 \%$} & & & \\
\hline
\end{tabular}

\section{Application Efficiency (Ea)}

Application efficiencies of irrigation systems and water application levels were highly significant at $(\mathrm{P}<0.01)($ Table 8$)$. As shown on Table 11, both of AFI and FFI systems and water application levels of 50\% ETc were significantly different from CFI system and $85 \%$ ETc, respectively, but no significant difference between AFI and FFI systems and the remaining of water application levels. Both irrigation systems and water application levels were better in application efficiency under low irrigation water depth application. This is because of the higher rate of lateral flow under low water depth application in sandy loam soil, which improves application efficiency rather than deep percolation losses. This is consistent with the significant improvements in application efficiency that have been associated with AFI and FFI (Feyen and Zerihun 1999; Kassa, 2001; Woldesanbet, 2005). 
Table 11. Effects of irrigation systems and water application levels on application efficiency

\begin{tabular}{|c|c|c|c|c|c|c|c|}
\hline \multirow{2}{*}{$\begin{array}{l}\text { WUE } \\
\text { parameters }\end{array}$} & \multicolumn{3}{|c|}{ Irrigation systems } & \multicolumn{4}{|c|}{ Water application levels } \\
\hline & CFI & FFI & AFI & $100 \%$ ETc & $85 \%$ ETc & $70 \%$ ETc & $50 \%$ ETc \\
\hline $\mathrm{Ea}$ & $55.28^{\mathrm{b}}$ & $59.22^{\mathrm{a}}$ & $60.45^{\mathrm{a}}$ & $59.56^{\mathrm{a}}$ & $56.48^{\mathrm{ab}}$ & $57.47^{\mathrm{abc}}$ & $59.78^{\text {ac }}$ \\
\hline Mean & & & & & & & \\
\hline $\mathrm{CV}$ & & & & & & & \\
\hline LSD0.05 & & & & & & & \\
\hline $\mathrm{SE} \pm$ & & 1.57 & & 1.67 & & & \\
\hline
\end{tabular}

There were highly significant interaction effect at $(\mathrm{P}<0.01)$ between irrigation systems and water application levels on application efficiency (Table 8). As observed from two ways (Table 12), application efficiency was significantly affected by water application levels of $100 \%$ ETc, $85 \%$ ETc and 70\% ETc under FFI system. While in AFI system, it was significantly affected at $85 \%$ ETc water application levels. Application efficiency of CFI system at $100 \%$ ETc was significantly different from the water application levels of $85 \%$ ETc, $70 \mathrm{ETc}, 50 \% \mathrm{ETc}$ and also between $85 \% \mathrm{ETc}$ and $50 \% \mathrm{ETc}$. This indicates that, application efficiency of CFI system was affected by water application levels.

Table 12.Two-way table of mean application efficiency $(\%)$

\begin{tabular}{|c|c|c|c|c|c|}
\hline \multirow{2}{*}{ Irrigation systems } & \multicolumn{4}{|c|}{ Water application levels } & \multirow[t]{2}{*}{ Mean } \\
\hline & $100 \%$ ETc & $85 \% \mathrm{ETc}$ & $70 \%$ ETc & $50 \% \mathrm{ETc}$ & \\
\hline FFI & $57.69^{\mathrm{a}}$ & $55.88^{\mathrm{a}}$ & $59.35^{\mathrm{a}}$ & $63.98^{b}$ & 59.23 \\
\hline AFI & $61.13^{\mathrm{a}}$ & $57.79^{\mathrm{b}}$ & $59.46^{\mathrm{ab}}$ & $63.41^{\mathrm{ac}}$ & 60.45 \\
\hline CFI & $59.85^{\mathrm{a}}$ & $56.14^{\mathrm{b}}$ & $53.62^{\mathrm{cb}}$ & $51.50^{\mathrm{c}}$ & 55.28 \\
\hline Mean & 59.56 & 56.60 & 57.48 & 59.63 & 58.32 \\
\hline $\mathrm{LSD}_{0.05}$ & \multicolumn{4}{|c|}{$\begin{array}{r}3.35 \\
320 \%\end{array}$} & \\
\hline $\mathrm{CV}(\%)$ & \multicolumn{4}{|c|}{$3.29 \%$} & \\
\hline
\end{tabular}

\section{Storage Efficiency $($ Er)}

According to the analysis of variance (Table 8), there was highly significant difference at $(\mathrm{P}<0.01)$ between the three irrigation systems and water application levels, but their interaction was none significant in terms of storage efficiency. The storage efficiency of CFI system was significantly different from AFI systems, while there was no significant difference between AFI and FFI systems. This is because of the irrigation technique, as all furrows was getting an opportunity of irrigated at once in CFI system, while it was turn by turn in AFI and the depth of applied irrigation water. There was a significant difference among all water application levels expect between 70\% ETc and 50\% ETc on storage efficiency. This result indicates that, as a water application levels become decreases under deficit irrigation, the storage efficiency is also decreases, as storage efficiency is a measure of adequacy when the desired depth of irrigation fills the soil to field capacity (James, 1988).

Table 13. Effects of irrigation systems and water application levels on storage efficiency

\begin{tabular}{|c|c|c|c|c|c|c|c|}
\hline \multirow{2}{*}{$\begin{array}{l}\text { WUE } \\
\text { parameters }\end{array}$} & \multicolumn{3}{|c|}{ Irrigation systems } & \multicolumn{4}{|c|}{ Water application levels } \\
\hline & CFI & FFI & AFI & $100 \%$ ETc & $85 \% \mathrm{ETc}$ & $70 \% \mathrm{ETc}$ & $50 \% \mathrm{ETc}$ \\
\hline $\mathrm{Er}$ & $65.77^{\mathrm{a}}$ & $65.13^{\mathrm{ab}}$ & $63.15^{\mathrm{b}}$ & $70.75^{\mathrm{a}}$ & $65.77^{\mathrm{b}}$ & $62.05^{\mathrm{c}}$ & $61.00^{c}$ \\
\hline Mean & \multicolumn{3}{|c|}{64.89} & & & & \\
\hline $\mathrm{CV}$ & \multicolumn{3}{|c|}{$2.23 \%$} & & & & \\
\hline $\mathrm{LSD}_{0.05}$ & \multirow{2}{*}{\multicolumn{3}{|c|}{2.46}} & 2.55 & & & \\
\hline $\mathrm{SE} \pm$ & & \multicolumn{2}{|l|}{1.18} & 1.28 & & & \\
\hline
\end{tabular}

\section{Deep Percolation Losses $(\mathrm{Dp})$}

From the analysis of variance (Table 8 ), irrigation systems and water application levels were highly significant at $(\mathrm{P}<0.01)$ on deep percolation losses. Deep percolation losses of CFI system and 85\% ETc water application level were significantly different from both of AFI and FFI systems and 50\% ETc, respectively. While, there was no significant difference between AFI and FFI systems and the remains of water application levels. This is consistent with the significant water loss that has been associated with CFI (Graterol et al., 1993). The result of present study was below the range of irrigation water losses reported by Kassa (2001).

Table 14. Effects of irrigation systems and water application levels on deep percolation losses

\begin{tabular}{|c|c|c|c|c|c|c|c|}
\hline \multirow{2}{*}{$\begin{array}{l}\text { WUE } \\
\text { parameters }\end{array}$} & \multicolumn{3}{|c|}{ Irrigation systems } & \multicolumn{4}{|c|}{ Water application levels } \\
\hline & CFI & FFI & AFI & $100 \%$ ETc & $85 \%$ ETc & $70 \%$ ETc & $50 \% \mathrm{ETc}$ \\
\hline $\mathrm{Dp}$ & $44.73^{\mathrm{a}}$ & $40.78^{b}$ & $39.55^{\mathrm{b}}$ & $40.44^{\mathrm{a}}$ & $43.40^{\mathrm{ab}}$ & $42.53^{\mathrm{abc}}$ & $40.30^{\mathrm{ac}}$ \\
\hline Mean & & & & & & & \\
\hline $\mathrm{CV}$ & & & & & & & \\
\hline $\mathrm{LSD}_{0.05}$ & & 3.09 & & & & & \\
\hline $\mathrm{SE} \pm$ & & 1.49 & & & & & \\
\hline
\end{tabular}


The interaction effects between irrigation systems and water application levels were highly significant at $(\mathrm{P}<0.01)$ on deep percolation losses (Table 8). As depicted on two ways Table 15, deep percolation losses under CFI system at 100\% ETc was significantly different from $85 \%$ ETc, $70 \%$ ETc, and 50\% ETc and also between $85 \%$ ETc and 50\% ETc water application levels. This shows that, a deep percolation loss in CFI system was not affected by water application levels, because as water application levels decreases deep percolation losses increases. Deep percolation loss was significantly affected under FFI system at 50\% ETc water application levels than the remaining water application levels. It shows that, as the applied irrigation depth decreases to below the maximum carrying capacity of the soil, it moves laterally towards the dry area rather than deep percolating. In AFI system, there were a significant difference between 100\% ETc and 85\% ETc, 85\% ETc and 50\% ETc, 70\% ETc and50\% ETc on deep percolation losses.

Table 15. Two-way mean of deep percolation $(\%)$

\begin{tabular}{|c|c|c|c|c|c|}
\hline \multirow[t]{2}{*}{ Irrigation systems } & \multicolumn{4}{|c|}{ Water application level } & \multirow[t]{2}{*}{ Mean } \\
\hline & $100 \%$ ETc & $85 \%$ ETc & $70 \%$ ETc & $50 \%$ ETc & \\
\hline FFI & $42.31^{\mathrm{a}}$ & $44.12^{\mathrm{ac}}$ & $40.65^{\mathrm{ad}}$ & $36.02^{\mathrm{b}}$ & 40.78 \\
\hline AFI & $38.87^{\mathrm{a}}$ & $42.22^{\mathrm{b}}$ & $40.53^{\mathrm{ab}}$ & $36.76^{\mathrm{ac}}$ & 39.55 \\
\hline CFI & $40.15^{\mathrm{a}}$ & $43.86^{\mathrm{b}}$ & $46.39^{\mathrm{cb}}$ & $48.50^{\mathrm{dc}}$ & 44.72 \\
\hline Mean & 40.44 & 43.40 & 42.52 & 40.37 & 41.68 \\
\hline $\mathrm{LSD}_{0.05}$ & 3.49 & & & & \\
\hline $\mathrm{CV}(\%)$ & $4.34 \%$ & & & & \\
\hline
\end{tabular}

Crop water use efficiency (CWUE) and Field water use (FWUE)

The three irrigation systems shows highly significant difference among them both in CWUE and FWUE at $(\mathrm{P}<0.01)$ (Table 8). But, water application levels and their interaction with irrigation systems were none significant. The analysis results (Table16) shows that, maximum water use efficiency was obtained from AFI system for both CWUE and FWUE. This is because of the difference in percentage of water actually converted to evapotranspiration out of the total amount applied. This is consistent with the significant improvements in CWUE that have been associated with AFI (Zhang et al., 2000).

Table 16. Effect of irrigation systems on crop and field water use efficiency

\begin{tabular}{cc}
\hline Irrigation systems & $(\mathrm{C} \& \mathrm{~F}) \mathrm{WUE}\left(\mathrm{kg} \mathrm{ha}^{-1} \mathrm{~mm}^{-1}\right)$ \\
\hline AFI & $256.69^{\mathrm{a}}$ \\
\hline FFI & $214.77^{\mathrm{b}}$ \\
CFI & $130.53^{\mathrm{c}}$ \\
\hline Mean & 200.66 \\
CV & $11.12 \%$ \\
LSD $_{0.05}$ & 37.79 \\
SE \pm & 18.22 \\
\hline
\end{tabular}

\section{Tomato yield performance}

As depicted from the analysis of variance (Table 8), there were highly significant yield difference at $(\mathrm{P}<0.01)$ between irrigation systems and water application levels. According to (Table17), the yield obtained from CFI and AFI systems were significantly different from FFI system. But, there was no significant difference between the yield obtained from CFI and AFI systems. However, the yields obtained from all water application levels were significantly different. The yield obtained in AFI system is well performing with CFI system under 50\% reduction in irrigation water. This is probably because of better application efficiency and physiological response associated with AFI (Zhang et al., 2000) and less evapotranspiration associated with AFI (Stone et al., 1979). The significant yield difference among the water application levels is consistent with the report of continuous water stress during the period of fruit set and fruit development can results significantly reduced fresh fruit yield and blossom-end rot (Sahasrabudhe, 1996).

Table 17. Effects of irrigation systems and water application levels on tomato yield performance

\begin{tabular}{cccccccc}
\hline Yield performance & \multicolumn{3}{c}{ Irrigation systems } & \multicolumn{3}{c}{ Water application levels } \\
\cline { 2 - 7 } & CFI & FFI & AFI & $100 \%$ ETc & $85 \%$ ETc & $70 \%$ ETc & $50 \%$ ETc \\
\hline yield & $25.194^{\mathrm{a}}$ & $20.00^{\mathrm{c}}$ & $24.021^{\mathrm{a}}$ & $31.879^{\mathrm{a}}$ & $24.574^{\mathrm{b}}$ & $20.794^{\mathrm{c}}$ & $15.038^{\mathrm{d}}$ \\
Mean & & & 23.072 & & & &
\end{tabular}

$\mathrm{CV}$

$8.7 \%$

$\begin{array}{ccc}\mathrm{LSD}_{0.05} & 1.696 & 1.959 \\ \mathrm{SE} \pm & 0.578 & 0.668\end{array}$

As shown on the analyses (Table 8) there were interaction effects of irrigation systems and water application levels on yield. According to (Table 18) the maximum yield was obtained from CFI with100\% ETc, while minimum yield were obtained from both FFI and CFI with 50\% ETc. This shows that, yield was highly affected by irrigation systems at $100 \%$ ETc water application level and in an area where water availability and quality is not a problem CFI with 100\% ETc was a promising. But, the irrigation water quality and quantity is decline from time to time and the needs of technology for irrigation water saving is becoming the issue of the day. And as already known, there was a significant reduction (50\%) in volume of water applied in AFI system. This means $2465.8 \mathrm{~m}^{3}$ volume of water is needed to irrigate 1 hectare area in CFI system which is enough to 
irrigate 2 hectare area of land in AFI system and the time saved in AFI system is (55:28'30" hours/ha). So, when the area to be irrigated becomes double in AFI system using the saved volume of water, the yield obtained also becomes double. In view of the above results, AFI system is a promising technology for farmers.

Table18. Two-way table of mean of yield $(\mathrm{Kg} / \mathrm{ha})$

\begin{tabular}{cccccc}
\hline \multirow{2}{*}{$\begin{array}{c}\text { Irrigation } \\
\text { systems }\end{array}$} & \multicolumn{4}{c}{ Water application level } & Mean \\
\cline { 2 - 5 } & $100 \% \mathrm{ETc}$ & $85 \% \mathrm{ETc}$ & $70 \% \mathrm{ETc}$ & $50 \% \mathrm{ETc}$ & \\
\hline FFI & $22,500.00^{\mathrm{a}}$ & $22,527.78^{\mathrm{a}}$ & $20,777.78^{\mathrm{a}}$ & $15,277.78^{\mathrm{b}}$ & $20,270.84$ \\
AFI & $31,444.44^{\mathrm{a}}$ & $24,777.78^{\mathrm{b}}$ & $21,694.44^{\mathrm{cb}}$ & $15,944.44^{\mathrm{d}}$ & $23,465.28$ \\
CFI & $38,694.44^{\mathrm{a}}$ & $25,500.00^{\mathrm{b}}$ & $21,861.11^{\mathrm{c}}$ & $15,555.56^{\mathrm{d}}$ & $25,402.78$ \\
\hline Mean & $30,879.63$ & $24,268.52$ & $21,444.44$ & $15,592.59$ & $23,046.30$ \\
\hline LSD $_{0.05}$ & 3,393 & & & \\
\hline CV $(\%)$ & $8.68 \%$ & & & \\
\hline
\end{tabular}

\section{CONCLUSIONS AND RECOMMENDATIONS}

1. Tomato needs high amount of irrigation water during the flowering and fruit setting stage and continuous stress significantly reduces fresh fruit yield, especially in FFI system as half of the root stay dry throughout the growth period.

2. The irrigation water used in AFI system is $50 \%$ of CFI system, but the tomato yield obtained was similar. Significant amount of water $\left(1232.9 \mathrm{~m}^{3} / \mathrm{ha}\right)$ was saved by AFI system while it also maintains an acceptable tomato yield. AFI and FFI systems saved cost (187502.00 birr/ha) and time (522:09'15" hr/ha) for one cropping season which is 50\% of CFI system. Because in CFI system four furrows irrigated at same time while in AFI and FFI only two furrows out of four furrows. This may improves working conditions as technology allows irrigator moving on the dry furrows. Rather than using $2465.8 \mathrm{~m}^{3}$ of water for 1 hectare in CFI system, it is possible to double the irrigated area to 2 hectares in AFI system

3. Over application and high frequency irrigation was a known constraint in the study area and giving training and advisory service for communities on how to use crop water requirement based irrigation system.

4. The experiment was carried out by constant inflow rate with different application time to manage water application levels. So, future research work should be needed with different inflow rate and irrigation interval.

5. Alternative furrow irrigation system is the best technology among the tested technologies to be recommended for the communities of the study area, because of its high water application efficiency both (CWUE and FWUE), yield performance, in addition to time and irrigation cost saving.

\section{ACKNOWLEDGEMENTS}

The authors would like to acknowledge International Water Management Institute (IWMI) and International Livestock Research Institute (ILRI) Livestock and Irrigation Value Chain for Small holders Farmers (LIVES) project for providing the required budget to conduct the experiment. Besides, I would like to thanks the laboratory technicians of Ethiopian Water Works Design and Supervision Enterprise, Bako and Ziway Research Center for their effective and dedicated work in soil analysis.

\section{REFERENCES}

[1] Allen, R.G., Pereira L.S., Raes D. and Smith M. 1998. Crop evapotranspiration: guidelines for computing crop water requirements. Irrigation and Drainage paper No 56. FAO, Rome.

[2] Bekele, S., Tilahun, K., 2007. Regulated deficit irrigation scheduling of onion in a semi arid region of Ethiopia. Agric. Water Mange. 89, 148-152.

[3] Cai X M, Rosegrant M W. 2003. World water productivity: current situation and future options. In: Kijne J W, Barker R, Molden D. Water Productivity in Agriculture: Limits and Opportunities for Improvement. Oxford: CAB Publishing and Colombo: IWMI, 163-178.

[4] Chen Y Q, Li X B, Wang J. 2011. Changes and effecting factors of grain production in China. Chinese Geographical Science, $21(6): 676-684$.

[5] Costa, J. M., Ortuno, M. F. and M. M. Chaves. 2007. Deficit irrigation as a strategy to save water : physiology and potential application to horticulture. J. Integr. Plant Biol. 49: 1421-1434.

[6] Cuenca, R.H. 1989. Irrigation System Design; An engineering approach. Oregon State University, Prentice hall, Engle wood cliffs New Jersey 07632 .

[7] FAO. 2001. AQUASTAT-FAO's Information systems on water and agriculture. Her //www. wcainfonet.org/cds_static/en/quastat_fao_information_system_water_ethiopia_en_569_1436.

[8] Feyen J. and D. Zerihun. 1999. Assessment of the performance of border and furrow irrigation systems and the relationship between performance indicators and system variables. Agricultural Water Management 40: 353-362.

[9] Graterol,Y.E., D.E. Eisenhauer and R.W. Elmore. 1993. Alternate furrow irrigation for soybean production. Agricultural Water Management, 24: 133-145.

[10] Hodges, M.E., J.F. Stone, J.E. Garton and D.L.Weeks. 1989. Varience of water advance in wide spaced furrow irrigation. Agricultural Water Management 16: 5-13.

[11] Israelsen, O.W., and Hansen, V.E. 1980. Irrigation Principles and Practices. Jonsen Wiley and Sons, Inc. New York, London.

[12] James G. 1988. Principle of Farm Irrigation System Design. John Wiley \& Sons, Inc. New York.

[13] Kassa Teddla. 2001. Performance evaluation of surface irrigation methods. Alemaya University.94 p.

[14] Kifle Mulubrehan and Gebretsadikan, T.G., 2016. Yield and Water Use Efficiency of Furrow Iirrigated Potato Under Regulated Deficit Irrigation, Atsibi-Wemberta, North Ethiopia. Agric. Water Manage. (2016), http://dx.doi.org/10.1016/j.agwat.2016.01.003

[15] Lemma Teklu. 2017. Effect of Furrow Irrigation Methods and Deficit Levels on Soil Properties and Yield of Tomato (Solanum Lycopersicum L.) at Dugda District, Central Rift Valley, Ethiopia. Vol. 6 Issue 04, April-2017. http://www.ijert.org. ISSN: 2278-0181.

[16] Lorite, I.J, Mateos L., Orgaz F., Fresses E. 2007. Assessing deficit irrigation strategies at the level of an irrigation district. Agricultural Water Management 91:51-60. http://dx.doi.org/ 10.1016/ j.Agwat. 2007.04.005.

[17] Michael, A.M. 2008. Irrigation Theory and Practice. $2^{\text {nd }}$ edn. Jupiter Offset Printers, Dehli-32.

[18] Musick, J.T., and D.A. Dusek. 1974. Alternate furrow irrigation of fine textured soils. Transaction of the ASAE pp 289-294. 
[19] Patane, C., Tringali, S. and O. Sortino. 2011. Effects of deficit irrigation on biomass, yield, water productivity and fruit quality of processing tomato under semi-arid Mediterranean climate conditions. Scientia Horticulturae, 129: 590 - 596.

[20] Peet, M. M. 2005. Irrigation and fertilization. In: Heuvelink E, ed. Tomatoes, Crop Production Science in Horticulture. CABI Publishing, UK. pp. 171-198.

[21] Sahasrabudhe, S.R.1996. Irrigation Engineering and Hydraulic Structures. S.K. Kataria and Sons. Delhi.

[22] Stone, J.F., J.E. Garton, B. B. Reeves and H.E. Keflemariam. 1979. Irrigation water conservation using wide-spaced furrows. Soil Sci. Am. J., 43: 407-411.

[23] Walker, W.R. 1989. Guidelines for Design and Evaluating Surface Irrigation System. FAO irrigation and drainage paper 45. Rome.

[24] Woldesenbet Gebre, 2005. Evaluating alternate furrow irrigation for potato production in sub-humid area of east Gojam, Alemaya University. 80p

[25] Zhang, J., S. Kang, Z. Liang., Y. Z. Pan, P. Shi, Y. H. Pan, Z. S. Liang, X. T. Hu. 2000. Soil water distribution, uniformity and water use efficiency under alternate furrow irrigation in arid areas. Irrigation Science 19: 181-190. 